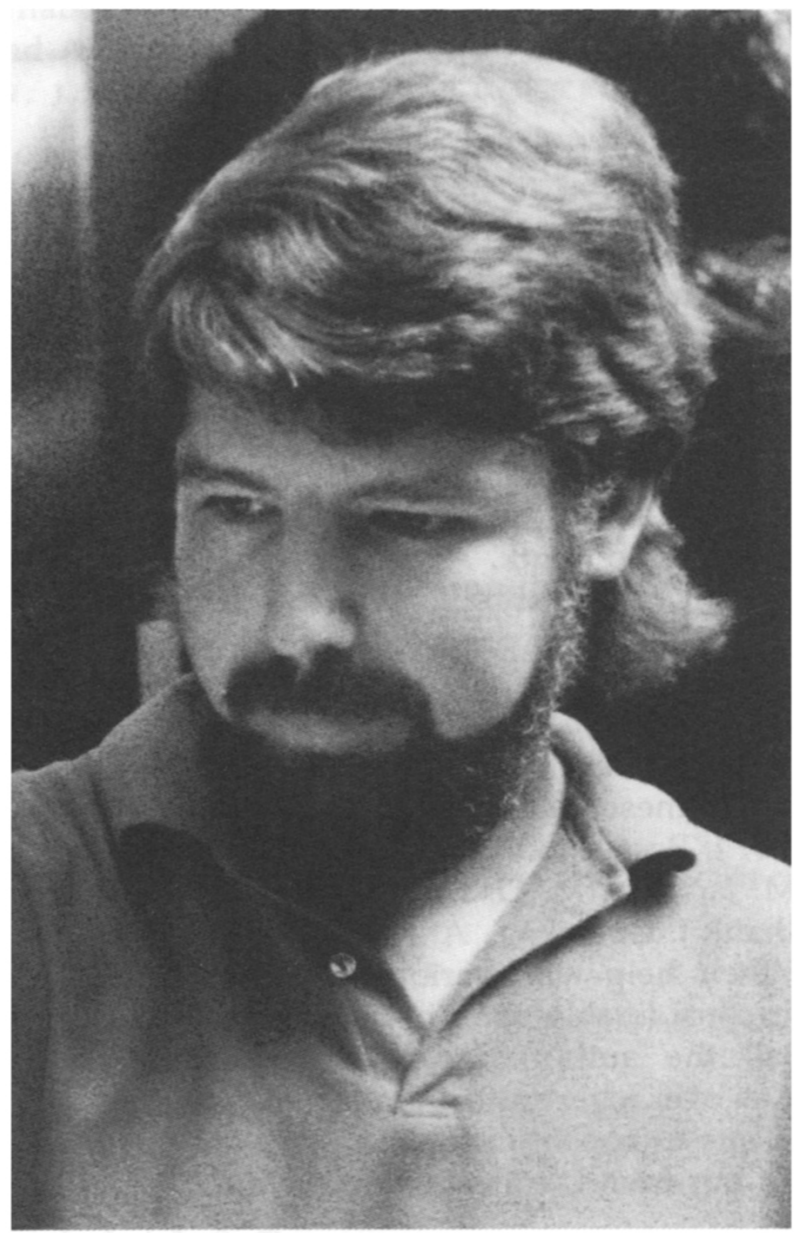

Ted Parker

1 April 1953-3 August 1993

Photograph courtesy of State Times/Morning Adrocate (Baton Ronge, Louistana) 


\title{
A tribute to Ted Parker
}

\author{
THOMAS S. SCHULENBERG
}

"I'd forgotten how trees full of bird sounds made you sense the world differently." (Barbara Kingsolver, The Bean Trees)

No one I have ever met was more attuned to bird sounds, or to birds in general, than was Ted Parker. It was from Ted that many of us, who thought that we already knew a thing or two about birds, truly learned how to sense the world.

No matter when one first met, or heard of, Ted Parker, the name was already a legend. I first met Ted over 20 years ago, and like many people at the time I was already somewhat in awe of him. Then he was known for his birding exploits in the United States and in Mexico. Although I did not realize it at the time, he was already studying the birds of South America, and soon would be transforming our understanding of the avifauna of that continent. By the end of the 1970s, within just a few years of his first trip to the Andes, and without benefit of field guides or commerical bird tapes, he was already the field ornithologist of South America.

The outlines of the legend are familiar enough, and have been tabulated in crude ways: the number of months, years spent travelling in the tropics; the numbers of countries and of sites visited; the dozens and dozens of discoveries of birds hundreds of miles "out of range"; and, the clincher, the ability to identify thousands of species of birds - the number seemed to grow larger with each telling of the story - by call or song alone. It is, I think, a sad commentary on our reductionist times that we feel so compelled to try to quantify whatever it was that made Ted so special - Ted who, of all people, had an adamantly non-reductionist approach to natural history, and who cared so little for efforts to reduce his vision of the world to tables and to piles of numbers.

It is hard to explain, to someone who never witnessed Ted in action, all that lay behind the legend. In many ways he made it all seem so easy. Nothing could compare to being in the field with Ted. Standing beside him, binoculars at the ready, was perhaps the most exhilarating experience of my life, because of the seemingly limitless possibilities in field observation that were revealed; and at the same time, no experiences of mine were as humbling, with the growing realization that the "possibilities" that were open to Ted just might not be open to me. Many times, as we both watched the same bird, I heard him whisper excitedly, "There! Did you see that?" He would be commenting, not on the bird itself, but on what it did, some motion it made, some behaviour 
it displayed, often subtle, and whether it fitted some pattern he'd seen before, or whether it made some motion that he wasn't expecting at all. Ted and I might have been watching the same bird, but time and time again, only one of us had seen it.

To those who were aware of his lacklustre achievements in traditional schoolwork, or who grew frustrated at the prodding that often was necessary to get him to finish a writing project, Ted gave the impression of being more that a little undisciplined. Steve Hilty once spent several days working in the Neotropical bird collections at Louisiana State University. While in Baton Rouge, Hilty stayed in the apartment that was shared by Ted and Mark Robbins, all of them being close friends since their student days at the University of Arizona. When it came time to leave LSU, Hilty duly appraised his hosts: "Robbins, you haven't changed a bit. And Parker, you've only gotten worse".

In fact Ted worked hard, very hard, at things in which he was interested, even in the early years when it seemed clear that society placed little value on the skills that he was mastering. Ted not only made tens of thousands of field recordings of bird songs, but he studied them, endlessly. He also knew the classical literature on Neotropical birds backwards and forwards, having not just read, but truly assimilated, much of it even before his first trips to South America. He returned often to the writings of Frank M. Chapman, who, like Ted, collected many facts but was ultimately more interested in synthesis.

Another early figure for whom Ted had great respect was the professional collector Melbourne A. Carriker, Jr. Ted described Carriker as "extraordinary," and twice retraced Carriker's footsteps in Peru: once to rediscover three rare bird species restricted to remote Polylepis woodland near Yanac in Ancash, and later to relocate the Yellow-browed Toucanet on the trail to Utcubamba, La Libertad.

In the field Ted seemed indefatigable. He didn't really like to suffer, but his approach to fieldwork was often so focused that he paid less attention to his surroundings than did the rest of us. Rising before dawn at one treeline camp at 3,400 $\mathrm{m}$, he would stumble around, barefoot, on the cold muddy ground; he explained that this way, when he finally put on his wet tennis shoes, his feet would not feel so cold!

Everything Ted saw in the field, he wrote down or dictated onto a tape; recording even seemingly inconsequential details about birds was an obsession for him. Ted wrote notes so that he would not forget what he had obseved. And yet, what was truly remarkable about Ted the field ornithologist was that it seemed that he never forgot anything about a bird that he had seen. Rather than becoming lost in the multitudinous details of his observations, Ted had an amazing ability to sift that internal storehouse, and produce novel and exciting syntheses. He was constantly searching for patterns, in distribution, foraging behaviour, vocalizations, flock dynamics, in almost any aspect of birds that attracted his attention. Given the stature Ted came to hold in tropical ornithology, it is staggering to think that only a few of his many ideas found their way into print during his lifetime.

Ted possessed a healthy ego, and a strong competitive streak. It was important to him that he gain the recognition that he thought he deserved (this was especially true in the early years, when he often felt that he was marginalized by 
the academic establishment, for his lack of post-graduate training). Sometimes, however, his own fame could come back to haunt him. Once he led a group of birdwatching tourists on a long hike to an oxbow lake on the Tambopata reserve in south-eastern Peru, and then, awkwardly, he paddled them around in a leaky canoe. Ted found the expected species, such as Hoatzin, and located a few less common birds as well, such as Sunbittern. Then all, including Ted, were astonished to see an adult Harpy Eagle flying towards them across the lake, carrying a Howler Monkey in its talons. After the great bird had disappeared, there was a moment of stunned silence. Then, from the back of the boat, someone called out: "That was nice, Ted. Now, if you can find us a Sungrebe, I'll buy you a beer."

I don't believe that Ted did find the Sungrebe that day, but sometimes he would boast that when he was in an area, no bird species would escape his detection. He knew that of course this was not true, but we knew that it was close enough to true that there were very real limits to how much we could rib him about it. Once, when he was participating in a project to study the ethnobiology of the Aguaruna Indians of northern Peru, he went off on a long excursion with several Aguaruna hunters. Ted knew that they would be entering areas where the recently described Orange-throated Tanager might be found, and he was fairly desperate to see this species. Ted and the Aguarunas hiked all day for several days through remote, steep valleys. Unfortunately, a friaje, a cold front, arrived during the trip, bringing hard rains and dampening bird activity. Disappointed at not finding the Orange-throated Tanager, Ted commented that "No birds sang the whole time that we were up there. I didn't see a thing." Although the circumstances were so grim that he "didn't see a thing", he did return with a sighting of the Blackish Pewee - only the second record for Peru of this poorly known species. Even when he "failed", Ted found birds that were the envy of the rest of us.

Impressive as was the legendary Ted Parker, the Ted who was my friend was truly extraordinary. I was but one of many, many people to whom Ted was generous with his time, knowledge, and encouragement. We'll miss him, always, but he will always be with us, wherever the trees are full of bird sounds.

\section{THOMAS S. SCHULENBERG}

Environmental and Conservation Programs, The Field Museum, Roosevelt Road at Lake Shore Drive, Chicago, IL 60605, U.S.A., and Conservation International, 1015 18th Street, NW, Suite 1000, Washington, D.C. 20036, U.S.A. 